\title{
《農芸化学技術賞》
}

\section{クレアチニン分解酵素群の開発および改良 一クレアチニン測定検査薬の高性能化を目指して一}

東洋紡績株式会社 西矢芳昭, 山本和巳，川村良久，愛水重典

クレアチニンは, 生体組織中に広く存在しているク レアチン，クレアチンリン酸の最終代謝産物として常 に一定量代謝され尿中へ排泄されている。土壤細菌の なかには，高等動物の老廃物であるクレアチニンを分 解して利用するあのが存在する．Pseudomonas 属や Bacillus 属などに属するこれらの細菌のクレアチニン 代謝経路は，2 種類知られている。一つは，クレアチ ニナーゼ (Crn), クレアチナーゼ (Cre) によりクレアチ ン、サルコシンへと分解し，ついでサルコシンオキシ ダーゼ(Sox)あるいはサルコシンデヒドロゲナーゼに よりグリシンまで分解する経路で，むう一つ，クレア チニンディミナーゼほかの計 4 種類の酵素によりメ チルヒダントインを経由して分解する経路がある。こ れらの酵素の特徵は, 精製醉素を用いて詳細に調べら れている.しかしながら, 酵素学的情報に比へ遺伝学 的情報は乏しく，各醉素遺伝子のゲノム上での関係や それぞれの発現調節に関する知見はなかった。

クレアチニン量は，外因性の影響あるいは腎以外の 影響を受けない，そのため，臨床検查において血中お よび尿中のクレアチニン量の測定は, 腎機能の程度を 知る最も良い指標となる，また，透析移行時の判定に
あ利用されている，従来，臨床検査で用いられている クレアチニンの定量法は，アルカリ性ピクリン酸を用 いる化学法が主であったが，呈色が弱く，種々の干渉 物質の影響を受け，さらに特異性に之しいという久点 を有している。近年, これらの欠点を補うものとして， 感度および精度に優れる醉素法が注目されてきてい る、酵素法は, Crn-Cre-Sox 酵素群を利用し, クレア チニン量に応じて生じる過酸化水素を，4-アミノアン チピリンーペルオキシダーゼ系で测定する（図 1).

しかしながら，本酵素法は多種多量の醉素を必要上 し，われわれが研究を始めた 1980 年代後半において は，安価な化学法に比べ価格的問題から普及が進んて いな加った。 また，現在の検查薬の形状は，従来の凍 結乾燥品に代わって使用時の利便性から液状夕イプが 主流となったが，液状検查薬に酵素法を用いるにはシ ビアな酵素性能が要求される，精製酵素に混入してい る微量のコンタミ醉素が試薬の出化をま的くため, 醉 素の高純度化が必要であり，長期間の液中での保存安 定性も重要亡なる。

このような背景から，われわれはクレアチニン分解 醉素群とその遺伝子の機能を解析し, 臨床的測定へ応

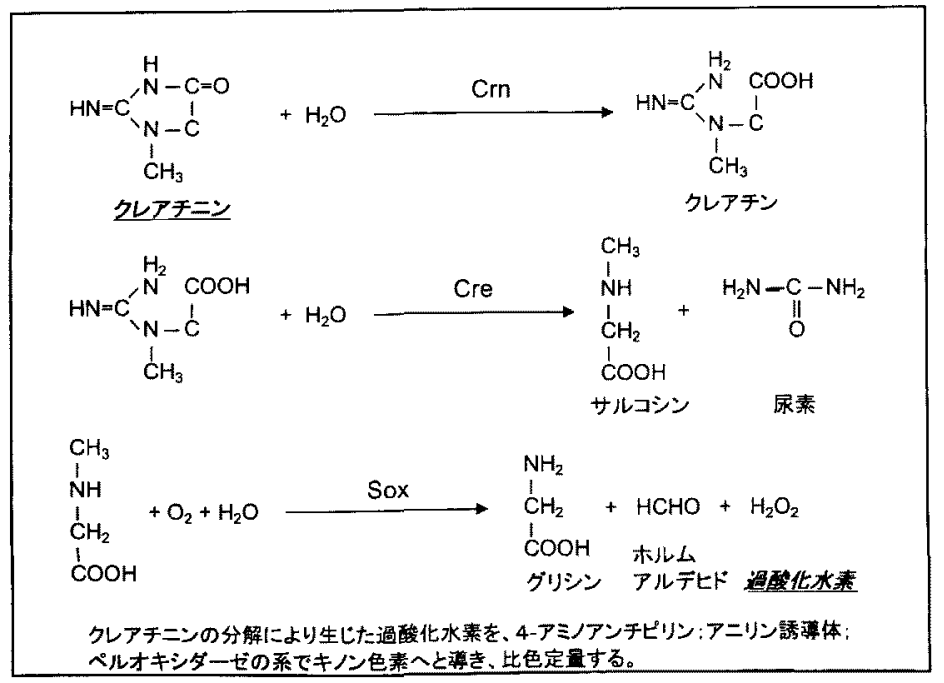

図 1 クレアチニンの酵素的測定原理 


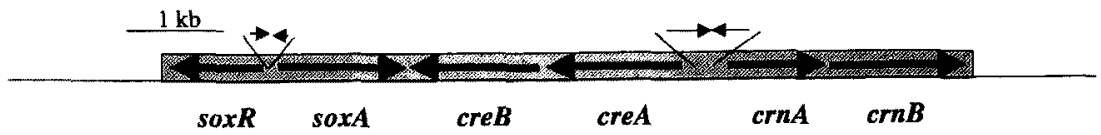

図 2 クレアチニン分艧酵素遺伝子クラスター

crm $A$, クレアチニナーゼ; creA, クレアチナーゼ; soxA, サルコシンオキシダーゼ; soxR, soxA のネガティブ レギュレーター; creB, crnB, トランスポーター様タンパク質

用することを目的として本研究を開始した．

\section{1. 分解菌の分離之同定}

まず，種々の土壤サンプルから分離した約 5 万株の 細菌を対象に，酵素活性を指標としてクレアチニン分 解性細菌をスクリーニングした，最終的に，生産する 酵素の活性，反応性（基質との親和性），および熱安定 性の面加ら，分解菌として 4 株を選抜，同定し，それ ぞれ Pseudomonas sp. PS-7, Actinobacillus sp. CRH1271, Alcaligenes faecalis TE3581，およびArthrobacter sp. TE1826 と命名した。 これらの菌より各醉 素を高純度に精製し醉素特性を調べることにより，臨 床検查薬用酵素として使用できることを確認した。特 に特性的に優れたPS-7 株の Crn, CRH-1271株の Cre 扩よびTE 1826 株のSox は製造工程の最適化と スケールアップを検討し，工業スケールでの生産を行 うことに成功した。

\section{2. 酳素遺伝子および関連遗伝子の解析}

それぞれの醉素の大量生産と高純度化を目指し，各 醳素遗伝子および関連遗伝子のクローニング之機能解 析を行った。 まず，PS-7 株より Crn 遗伝子を単離す ることに成功し， C r n の配列が初めて明らかとなっ た。さらに，TE1826 株よりクレアチニン分解酻素遗 伝子拉よびその周辺遺伝子をすべてクローニングし，

全塩基配列を決定した，結果として，クレアチニン分 解酵素遺伝子がクラスターとして存在することを初め て明らかにした（図 2)。この中には，負の調節遺伝子 1 種抢よびトランスポーターと相同性の高いタンパク 質の遗伝子 2 種む含まれていた，それぞれの遺伝子を 有する発現プラスミドを構築し，組換え菌で高発現さ せ，大量生産のための素地を固めた。

また，醉素の高純度化の一つの手段として，わ机わ れは新規な宿主一べクター系である Serratia liquefaciensの系を開発した。この系は宿主の生有最適温度が $25 \sim 30^{\circ} \mathrm{C}$ と低く，熱処理にて容易にコンタミ醉素を 除くことができる。

ついでわれわれは，組換え菌を用いた酵素の工業生 産について安全性の面加ら唡討を行った，その後，厚
生省より組換え DNA 技術応用医薬品等製造のための 指針に適合することの確認を受け，工業スケールでの 生産に移行している。これらは現在，クレアチニン測 定用醉素上して，液状検査薬を含む種々の臨床検查薬 に役立てられている。

\section{3. タンパク質工学的手法による酵素の機能改変}

実用的酵素に抢ける遗伝子組換え技術の目的は，单 なる生産性向上から醉素タンパク質の機能上構造の関 係を解析し，さらにタンパク質工学技術を用いて，安 定性向上や基質特異性の改善なよ゙の醉素の機能改变の 段階にきている，われわれは，臨床検查分野の先駆け 的な研究として，Sox の機能解析をタンパク質工学的 手法により試みた

まず，ランダム変異および部位特異的变異により基 質特異性を改変し, pH プロファイルとの関連を調ベ た．次に，ハイドロパシープロファイルでの構造予測 を基に選択したシステイン残基 (C-265)を置換し，安 定性や薬剤抵抗性を大幅に改善することができた（図 3). 種々の変異体の解析から, 活性中心にシステイン 残基 (C-318) が含まれること，アミノ末端側に補酵素 結合部位が，カルボキシ木端側に基質結合部位がそれ ぞれ存在することが判明した。また，塩素イオンが Sox 之補䣼素の相互作用に対し効果的であることを

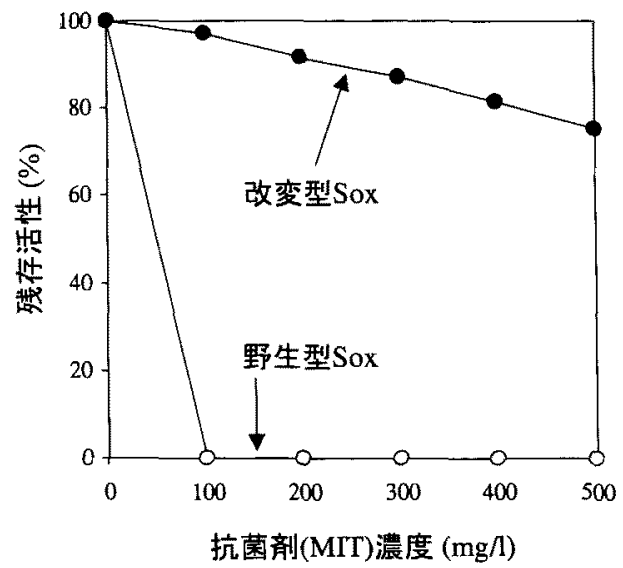

図 3 抗菌剤存在下での残存活性 


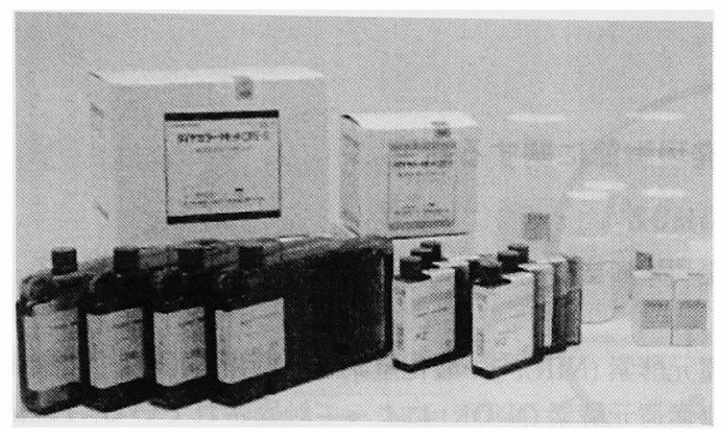

図 4 液状クレアチニン検査薬と原料酵素

発見しここれを臨床検査に応用した。

安定性が向上した改変型Sox は1995 年に商品化 され，現在では種々の臨床検査薬に用いられている， このようにタンパク質工学の成果が商品化に結びつい た例はまだまだ少なかったので, Sox の機能改変の成 功は意義深いもの之考える. その後，さまざまな機能 改変型の臨床検査薬用酵素が商品化されるようになっ た. 今後は, タンパク質構造解析技術やタンパク質工 学技術をさらに発展させ, 酵素特性を酵素の高次構造 と結びつけた普遍的な機能改变技術の確立が期待され る.

\section{4. 液状クレアチニン検査薬の開発}

われわれは，原料酵素の開発という形で臨床検査分 野の発展に寄与したいと考えているが，それぞれの醉 素特性を活功した㭘査薬の開発も行った。 その結果, 組換え Crn, Cre, および改変型 Sox を用いて, 高感度 な液状クレアチニン検査薬を開発することができた
（図 4）。本検査薬は 1997 年に厚生省の医薬品製造承 認を受け, 商品化した。現在, 精度的に優れた検査結 果を得ることのできる高性能検査薬として，臨床検査 のレベルアップに貢献している.

以上のように, クレアチニン分解酵素群を種々の微 生物より見いだし，䤃素特性を調べるとともに，遺伝 子工学技術およびタンパク質工学技術により実用化を 可能にした，今回，遺伝子レベルでの基礎的研究から 工業生産を目指した応用的研究，そしてスケールアッ プと工場における生産の立ち上げまでのすべてのステ ップを一貫して行うことができた。これにより，従来 精度や感度の面で問題の多かった化学法によるクレア チニン測定から, 精度, 感度共に優れる酵素法への移 行が進み, 工業的な成功はもちろんのこと, 臨床検査 技術が向上することで社会への貢献む果たすことがで きたのではと考える．開発したクレアチニン分解酵素 群は, 海外展開も果たしている. 今後, さらに本研究 開発を発展させていきたい.

最後に, 本研究の遂行にあたって, 京都大学・今中 忠行教授, 長崎大学・芳本忠教授, 崇城大学・鶴大典 教授（長崎大学名誉教授）をはじめとする諸先生方に 数々のご指導をいただいた. 各先生方に厚く御礼申し 上げる.また，本研究開発の成果は，東洋紡績株式会 社・敦賀バイオ研究所において, 歴代上司, 諸先輩の ご指導およびご支援の下，多数の共同研究者のご協力 によって達成されたものである．皆様に，心より謝意 を表する。 